\title{
California spiny lobster preference for urchins from kelp forests: implications for urchin barren persistence
}

\author{
J. G. Eurich, R. L. Selden*, R. R. Warner \\ Department of Ecology, Evolution, and Marine Biology, University of California, Santa Barbara, California 93106, USA
}

\begin{abstract}
Overfishing of urchin predators, in combination with natural disturbances, has been linked to an increase in the occurrence of urchin barrens. Marine reserves have been proposed as a means to re-establish the interactions between urchins and their predators in California kelp forests. Whether increased densities of lobsters and other predators in reserves are sufficient to convert barrens back to kelp forests depends on the degree to which predators avoid urchins from barren habitats. Urchins from these barrens may be less appealing to predators due to their diminished gonad production and thus decreased quality. In this study, we compared consumption rates of California spiny lobster Panulirus interruptus on purple urchins Strongylocentrotus purpuratus that were collected from kelp forests or from urchin barrens. All size classes of lobster prefer urchins from kelp forests relative to those from barrens and will actively select kelp-bed urchins when given a choice. Lobsters also showed higher consumption rates of kelp-bed urchins when either kelp-bed or barren urchins were presented alone. The large size class of lobsters consumed more and larger urchins than did smaller size classes of lobsters. These results suggest a potential mechanism for the persistence of urchin barrens despite high lobster densities and indicate that lobster foraging preferences may delay phase shifts from barrens back to kelp forests. The results also suggest that preferential foraging by lobsters on kelp-bed urchins may increase the resistance of kelp-beds to changes in state.
\end{abstract}

KEY WORDS: Lobster - Panulirus · Urchin - Strongylocentrotus · Kelp forest · Urchin barren · Predation · Phase shift

Resale or republication not permitted without written consent of the publisher

\section{INTRODUCTION}

Overfishing has led to phase shifts in a wide array of marine ecosystems, from tropical coral reefs to temperate kelp forests. For example, several studies suggest that the removal of herbivorous coral reef fishes by fishing allows macroalgae to overgrow corals, leading to a shift from coral to macroalgal dominated states (McCook 1999, Nyström et al. 2000, Scheffer et al. 2001, Hughes et al. 2007, Mumby 2009, Norström et al. 2009, Bellwood et al. 2011, Blackwood et al. 2012). Likewise, fishing of urchin predators in temperate kelp forests may have limited their ability to control herbivorous urchin populations, an important factor leading to the increased occurrence of urchin barrens (i.e. areas devoid of macroalgae) (Tegner \& Levin 1983, Tegner \& Dayton 2000, Lafferty 2004, Ling et al. 2009).

Various management solutions have been implemented to bring degraded ecosystems back to their natural healthy state. Of these, marine reserves have been recommended as a possible solution to initiate phase shifts to more desirable states (Dayton et al. 2000, Lester et al. 2009, Ling \& Johnson 2012). If a previous shift in ecosystem state was associated with increasing prey populations following the removal of 
predators, it is expected that increased predator densities inside reserves should re-establish prior interactions and top-down control of prey populations. Interestingly, after predator numbers rebound due to protection, the anticipated effects in terms of phase shifts have often taken longer than expected (i.e. on time scales of multiple years or decades; Micheli et al. 2004, Edgar et al. 2009, Babcock et al. 2010). A decadal-scale analysis of marine reserves showed that direct effects on targeted species are detected fairly quickly post-closure, but knock-on effects on prey significantly lag behind the recovery of their predator populations (Babcock et al. 2010).

This time lag between an increase in predator populations and a decline in their prey may be due to changes in predator or prey behavior that reduce the strength of their interaction. Predator-mediated reductions in activity, cryptic responses, and other prey behavioral changes that reduce encounter rates with predators may mediate the effects of increases in predator numbers, and thus prey species may not show the anticipated results as quickly as predatory species (Micheli et al. 2004, Babcock et al. 2010). It is also possible that predators are avoiding prey because the present ecosystem state has reduced prey quality. In this case, predators may encounter prey but choose not to consume them because of their low quality. For example, the macroalgal communities that replace corals often contain physical or chemical deterrents that make them less palatable and digestible for herbivores than other more common algal forms (Green \& Bellwood 2009), so herbivores may avoid eating some macroalgae even as their populations recover. In fact, optimal foraging theory suggests that predators will avoid low quality prey until the abundance of their preferred prey is below a 'switching threshold' (Krivan \& Sikder 1999). As a result, consumption of prey that lead to phase shifts may not occur until the abundance of other more preferred prey declines below the switching threshold for a predator. Understanding how predator diet preferences are related to the ecosystem state may help inform our expectations of community change and phase shifts following marine reserve establishment.

In the Southern California Bight, USA, kelp deforestation events have been attributed to several factors including fishing of urchin predators, sewage, and the high temperatures and storms associated with El Niño years (Tegner \& Levin 1983, Foster \& Schiel 2010). Urchin barrens have formed in their place either as a direct result of the loss of kelp cover or in response to the low drift kelp availability following a deforestation event (Harrold \& Reed 1985,
Lafferty \& Kushner 2000, Lafferty 2004). These barrens drastically limit ecosystem biodiversity (Graham 2004) and can exist in a kelp-free state for extended periods of time, as documented in Eastern Canada (Chapman 1981) and Southern California (Graham 2004). In addition to decreasing the prey species composition available for predators, barrens can also cause shifts in prey quality because food for prey is limited. In general, the urchins that cause the barrens appear to suffer from starvation and are forced to partition resources to other metabolic activities in order to stay alive, resulting in reduced gonad tissue production (Lawrence 2001, Stewart \& Konar 2012). Conversely, urchins from kelp forests allocate large fractions of energy towards reproduction, resulting in much larger gonads (Dodge \& Edwards 2011). This pattern has been observed for red urchins Strongylocentrotus franciscanus and purple urchins S. purpuratus in the Southern California Bight (Claisse et al. 2013). These gonads are what urchin predators target and consume and are therefore thought to be the primary driver behind predation (Tegner \& Levin 1983). Since a reduction in gonad production in barrens reduces individual quality, predators may avoid consuming urchins from barrens. As a result, phase shifts may not occur in reserves until the abundance of other preferred prey is reduced to the point that foraging on urchins in the barrens becomes profitable again or the urchins die from disease (Behrens \& Lafferty 2004) or are removed by storms (Ebeling et al. 1985). This mechanism has yet to be explored as a potential explanation for the persistence of urchin barrens observed in marine reserves.

To make accurate predictions about trajectories of community change following marine reserve establishment, it is critical to understand whether urchin predators can distinguish between kelp-bed and barren urchins, and if predators prefer urchins from kelp-beds. In this study, we examined the preferences of the California Spiny lobster Panulirus interruptus for urchins from kelp-beds versus barrens in a laboratory setting in order to understand how the diet preferences of this important urchin predator may influence the likelihood of a phase shift from barrens to kelp forest. For simplicity we refer to the urchin's origin and dietary feeding regime - a proxy for its nutritional status - as the 'urchin-state', i.e. either kelp-bed or barren. We hypothesized that lobsters could distinguish between the 2 urchin-states and would prefer to consume kelp-bed urchins. By knowing if a lobster can detect the urchin-state before expending energy and valuable foraging time on cracking and consuming the urchin, we can make 
predictions about the temporal nature of urchin barren dynamics. We also examined predator preferences as a function of urchin size. We hypothesized that the preference for kelp-bed urchins relative to barren urchins would be strongest with large urchins because of the increased handling time associated with longer spine canopies (Tegner \& Levin 1983, Ling \& Johnson 2009).

\section{MATERIALS AND METHODS}

Lobsters were collected by means of fishing pots from kelp forests on the South side of Santa Cruz Island, California (33⒌179' N, 119 39.345' W) and transported directly into aquaria. Nine lobsters were used during the trial; 3 large (carapace lengths of 114, 112, and $111 \mathrm{~mm}), 3$ medium (96, 94, and $92 \mathrm{~mm})$, and 3 small $(84,84$, and $83 \mathrm{~mm})$. All lobsters were allocated separate 2041 tanks with running sea water at ambient temperatures and air bubblers. Lobster dens were constructed out of cinderblocks and tiles and shaded to mimic a natural rocky den. Lobsters were fed purple urchins once every $3 \mathrm{~d}$ for 2 mo as they acclimated to the tanks.

Purple urchins were collected either from kelp forests off Refugio State Beach, Santa Barbara, California $\left(34^{\circ} 27.628^{\prime} \mathrm{N}, 120^{\circ} 3.893^{\prime} \mathrm{W}\right)$, or rocky barrens off Goleta Beach, Santa Barbara (34ํ⒉900' N, $119^{\circ}$ $49.763^{\prime}$ W). Kelp-bed urchins were kept in an aquarium, which was fully stocked with kelp, while barren urchins were kept in a separate aquarium and left unfed. Further gonad analysis of urchins collected from the 2 sites was used to confirm these feeding regimes kept the urchins at their original nutritional status. Kelp was re-stocked weekly and consisted primarily of Macrocystis pyrifera and Egregia menziesii.

\section{Relative preference for urchin-state}

In order to test the hypothesis that lobsters preferred kelp-bed urchins, lobsters were given both kelp-bed and barren urchins simultaneously and predation was observed. In order to distinguish individuals from the 2 urchin states in a mixed presentation, urchins were tagged. Urchins were pierced through the oral and aboral surface using a hypodermic needle through the test, avoiding the mouth, gonad tissue, and intestinal tracts (Ebert 1965, McClanahan \& Muthiga 1989). Fishing line was threaded through the needle, and a colored bead was attached. Urchins were given $1 \mathrm{wk}$ to heal before being used in a trial; previous studies suggest that this is sufficient time to allow reformation of the skeleton at the tagging site (Heatfield 1971). A total of 449 urchins were tagged using this method, with a $99 \%$ survival rate.

A single lobster was offered 5 kelp-bed urchins and 5 barren urchins of the same size class: small (test diameter 20 to $35 \mathrm{~mm}$ ), medium (36 to $50 \mathrm{~mm}$ ) and large (51 to $65 \mathrm{~mm}$ ). Sizes were standardized within each presentation, and no differences in size were observed between urchin states. Urchins were then randomly placed in a line orthogonal to the lobster den to ensure initial proximity did not affect lobster preference and were allowed to move freely. After a $24 \mathrm{~h}$ period, lobster predation was recorded and the remaining urchins were taken out of the tank. Lobsters were given a $3 \mathrm{~d}$ starvation period before undergoing the next trial. Similarly, surviving kelp-bed and barren urchins were put back in their respective feeding regimes for a minimum of $3 \mathrm{~d}$ before being used again in a trial. Each lobster underwent 2 trials per size class of urchin (total of 6 trials per lobster) in a randomly assigned order. Trials where predation was not observed were omitted from preference analysis (i.e. large lobsters $n=1$, medium lobsters $n=5$, small lobsters $n=8$ ).

\section{Absolute preference for single urchin-state}

In order to test if the preference observed was maintained when urchins of each state were presented alone, similar trials were run with one state of urchin at a time. Lobsters were given 5 urchins from a single state, and predation during a $24 \mathrm{~h}$ period was recorded. The same methods used in the preference experiments were used throughout the single urchinstate experiments.

\section{Urchin gonad tissue analysis}

To evaluate whether gonad differences could explain differences in consumption rates, gonad dry weights were measured for urchins in the 2 feeding regime urchin-states. After undergoing the feeding treatment, 15 urchins of each of the kelp-bed and barren states were randomly selected for dissections. Test diameter and width were measured to calculate the test volume (oblate spheroid). The tests were broken perpendicular to the oral surface in such a way that gonad tissue was not affected and a single full gonad was extracted. Gonad tissue was dried in an 
oven set to $60^{\circ} \mathrm{C}$ and weighed after $24 \mathrm{~h}$, then again after $48 \mathrm{~h}$ to ensure that no additional water loss occurred. The dry weight of a single gonad $(\mathrm{g})$ as a function of the urchin volume $(\mathrm{ml})$ was compared between urchin-states.

Gonad dry weight was also quantified for fieldcollected urchins: 30 urchins per site (Refugio, kelpbed; and Goleta Beach, barren) were compared to the lab urchins to evaluate whether original gonad condition was maintained.

\section{Data analysis}

All data were analyzed using R v. 2.12 (R Development Core Team 2011). For the trials where kelp-bed and barren urchins were offered simultaneously, a binomial generalized linear mixed model was used to evaluate the effects of urchin state, lobster size, and urchin size on the proportion of urchins eaten in each trial (Crawley 2007, Zuur et al. 2009). To account for the fact that consumption rates of kelp-bed and barren urchins were linked by being offered within the same tank, tank was considered as a random factor in the mixed model using the R package lme4 (Bates et al. 2011, Gosnell \& Gaines 2012). A binomial generalized linear model was used for the single-state urchin trials. For both the preference and single-state trials, a full model was fitted with all explanatory variables and interactions. From this full model, we subsequently generated simpler models and used the Akaike information criterion (AIC) to choose the most parsimonious model with the lowest AIC (Table 1). Graphical model validation techniques of the minimally adequate model showed no trends in the residuals nor did the residuals deviate from normality as determined from a qqplot. The impact of fixed factors in the minimally adequate model was assessed using Wald $Z$-tests, which are appropriate for models without overdispersion (such as in this study) (Bolker et al. 2009). For the gonad analysis, differences in gonad dry weight between urchin states was analyzed as an ANCOVA to account for differences in gonad weight as a function of urchin volume. Differences in slopes and intercepts among groups were analyzed using $t$-tests.

\section{RESULTS}

\section{Relative preference for urchin state}

Predation rates were higher on kelp-bed urchins when offered simultaneously with barren urchins. A preference for kelp-bed urchins was observed for all size classes of lobster (Fig. 1, Wald $Z=2.7, \mathrm{p}=0.007$ ). Holding all else constant, the odds of being eaten was more than 2.5 times higher for kelp-bed urchins than barren urchins (Table 2).

Consumption rates increased with lobster size. Relative to small lobsters, large lobsters consumed more urchins (Wald $Z=2.8, \mathrm{p}=0.004$ ), while medium and small lobsters consumed similar numbers of urchins (Wald $Z=1.3, \mathrm{p}=0.18$ ). The odds of being eaten by a large lobster were 3 times higher than that of being eaten by a small lobster (Table 2).

Losses to predation decreased with urchin size. Relative to small urchins, predation rates were signif-

Table 1. Results from model fitting for each experiment. The minimally adequate model was chosen according to the lowest Akaike information criterion (AIC). Conditional $\mathrm{R}^{2}$ derived by Nakagawa \& Schielzeth (2013); explained deviance = (null deviance - residual deviance)/null deviance (Zuur et al. 2009). GLM: generalized linear model; GLMM: generalized linear mixed model. U: urchin; L: lobster

\begin{tabular}{|c|c|c|c|}
\hline Experiment & Model & AIC & Goodness of fit \\
\hline Relative preference & Binomial GLMM & & Conditional $\mathbf{R}^{2}$ \\
\hline Full model & $\begin{array}{c}\text { Usize }+ \text { Ustate }+ \text { Lsize }+ \text { Usize } \times \text { Ustate }+ \text { Lsize } \times \text { Ustate }+ \\
\text { Lsize } \times \text { Usize }\end{array}$ & 269.92 & 0.28 \\
\hline Minimally adequate model & Usize + Ustate + Lsize + Usize $\times$ Ustate & 259.64 & 0.28 \\
\hline Absolute preference & Binomial GLM & & Explained deviance \\
\hline Full model & $\begin{array}{c}\text { Usize }+ \text { Ustate }+ \text { Lsize }+ \text { Usize } \times \text { Ustate }+ \text { Lsize } \times \text { Ustate }+ \\
\text { Lsize } \times \text { Usize }\end{array}$ & 69.7 & 0.93 \\
\hline Minimally adequate model & Usize + Ustate + Lsize & 63.5 & 0.83 \\
\hline Gonad & ANCOVA & & Adjusted $\mathbf{R}^{2}$ \\
\hline Full model & Site + Volume + Volume $\times$ Site & -177.00 & 0.76 \\
\hline Minimally adequate model & Volume + Volume $\times$ Site & -181.9 & 0.76 \\
\hline
\end{tabular}



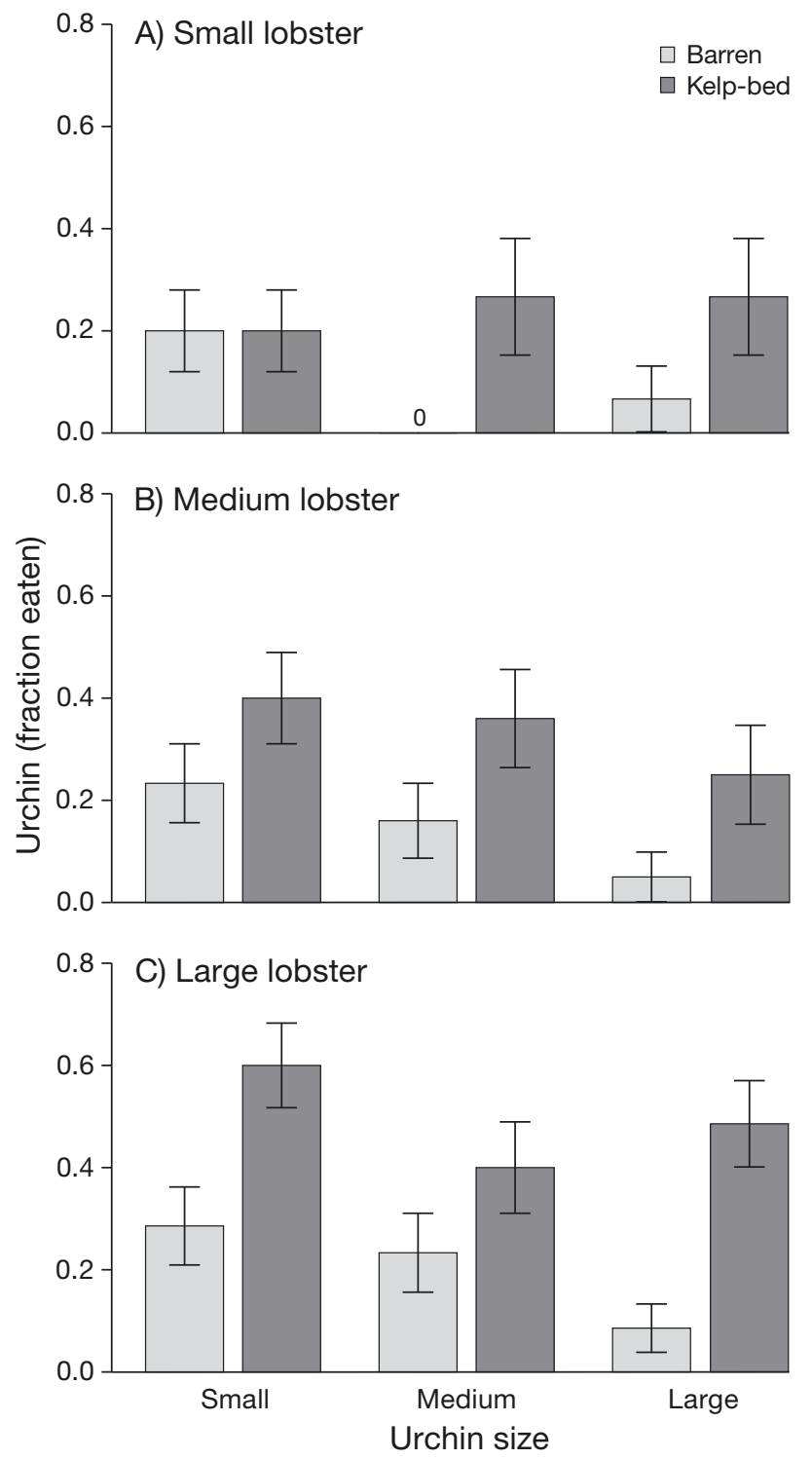

Fig. 1. Urchin predation rates, shown as the proportion of urchins eaten $( \pm 1 \mathrm{SE})$ when presented with kelp-bed (dark gray) and barren (light gray) urchins simultaneously. (A) Small lobster, (B) medium lobster, and (C) large lobster. No predation shown by a ' 0 '

icantly lower for large urchins (Wald $Z=-2.7, \mathrm{p}=$ 0.007 ), while predation on medium urchins was similar to small urchins (Wald $Z=-1.2, p=0.19$ ). The odds of being eaten as a large urchin were 0.19 that of being eaten as a small urchin (Table 2).

The interaction between urchin size and urchin state was marginally significant $\left(\chi^{2}=4.38\right.$, $\mathrm{df}=2, \mathrm{p}=$ $0.11)$, with the disparity in predation rates on kelp and barren urchins significantly greater for large urchins relative to small urchins (Wald $Z=1.97, \mathrm{p}=$ 0.048). Model fit is shown in Table 1.
Table 2. Results from a generalized linear mixed model with trial and lobster ID as a random effect for the kelp-bed and barren urchin state mixed trials. S: small; M: medium; L: large. The odds ratio (OR) was calculated by exponentiating the coefficients from the logistic regression to compare the odds of being eaten relative to the baseline scenario (a small lobster consuming a small barren urchin) (Rita \& Komonen 2008). Upper and lower $95 \%$ confidence intervals of the OR are shown. Wald $Z$ and p-values show significant differences in the level of the factor relative to baseline

\begin{tabular}{|lccccc|}
\hline Factor & $\begin{array}{c}\text { Odds } \\
\text { ratio }\end{array}$ & $\begin{array}{c}\text { Lower } \\
95 \% \text { CI }\end{array}$ & $\begin{array}{c}\text { Upper } \\
\text { 95 CI }\end{array}$ & $\begin{array}{c}\text { Wald } \\
Z\end{array}$ & $\mathrm{p}$ \\
\hline Lobster size & & & & & \\
S & 1 & & & & \\
M & 1.7 & 0.76 & 3.93 & 1.3 & 0.18 \\
L & 3.12 & 1.44 & 6.78 & 2.8 & 0.004 \\
Urchin size & & & & & \\
S & 1 & & & & \\
M & 0.53 & 0.20 & 1.38 & -1.2 & 0.19 \\
L & 0.19 & 0.06 & 0.64 & -2.7 & 0.007 \\
Urchin state & & & & & \\
Barren & 1 & & & & \\
Kelp-bed & 2.54 & 1.29 & 4.98 & 2.7 & 0.007 \\
Urchin size: urchin state & & & & \\
S:Barren & 1 & & & & \\
M:Kelp-bed & 1.30 & 0.44 & 3.8 & 0.48 & 0.63 \\
L:Kelp-bed & 3.63 & 1.01 & 13.03 & 1.97 & 0.048 \\
\hline
\end{tabular}

\section{Absolute preference for single urchin state}

Predation rates were also higher on kelp-bed urchins relative to barren urchins when presented alone (Wald $Z=2.7, \mathrm{p}=0.006$ ). The medium and small lobsters both had higher predation rates on kelp-bed urchins when offered alone (Fig. 2), and the small lobsters never consumed barren urchins. In contrast, the large lobsters consumed kelp-bed and barren urchins at a comparable rate.

Predation rates increased with lobster size $\left(\chi^{2}=\right.$ 57.7, df $=2, \mathrm{p}<0.001$ ), with overall higher consumption rates by the largest lobster. Predation rates decreased with urchin size $\left(\chi^{2}=37.319\right.$, df $=2$, $\mathrm{p}<$ 0.001). Model fit is shown in Table 1.

\section{Urchin gonad tissue analysis}

No differences in gonad dry weight were found between kelp-bed and barren urchins at the smallest urchin volumes (all p > 0.5, Fig. 3). Gonad dry weight increased with urchin volume $(t=2.611, \mathrm{p}=$ 0.01 ), but the rate of increase depended on urchin state $(F=55.298, \mathrm{p}<0.001)$. Relative to barren urchins, gonad dry weight increased more quickly 


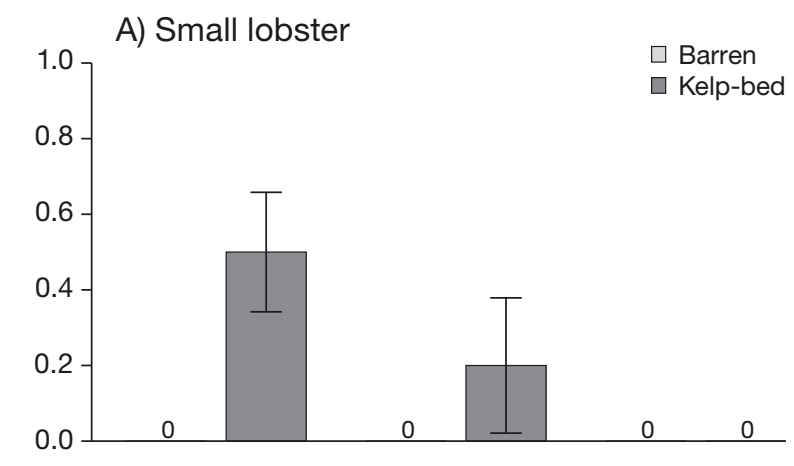

B) Medium lobster

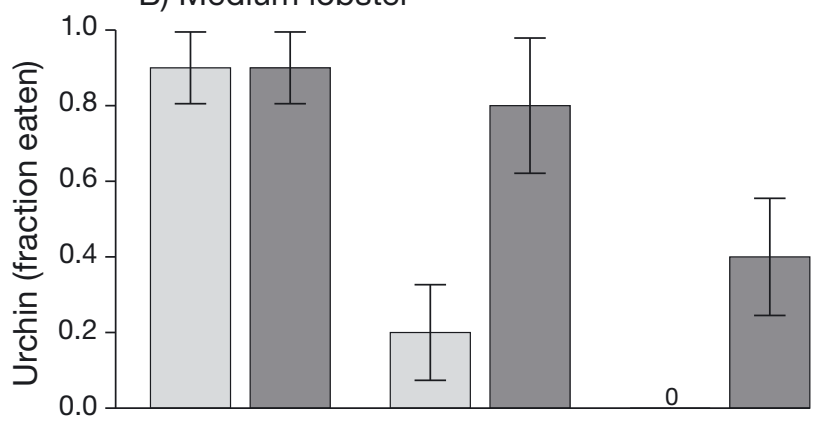

C) Large lobster

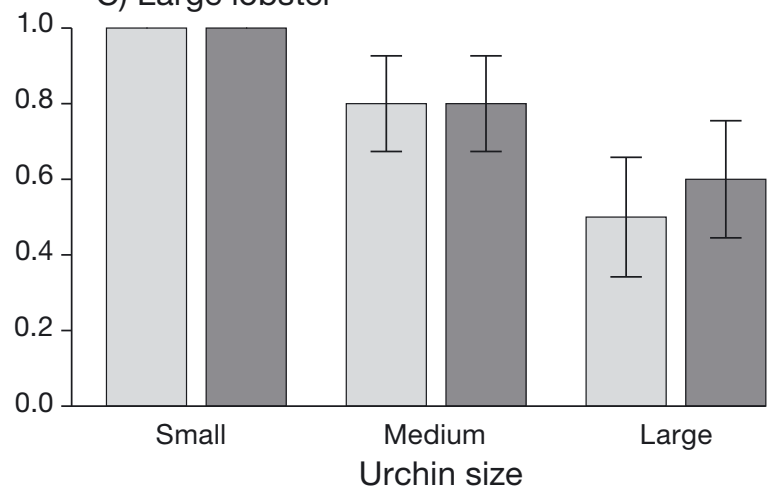

Fig. 2. Urchin predation rates, shown as the proportion of urchins eaten $( \pm 1 \mathrm{SE})$ when kelp-bed (dark gray) and barren (light gray) urchins were presented alone. (A) Small lobster, (B) medium lobster, and (C) large lobster. No predation shown by a ' 0 '

as a function of urchin volume for kelp-bed state urchins (Fig. 3, lab $t=4.434, \mathrm{p}<0.001$, field $t=$ $7.811, \mathrm{p}<0.001)$, leading to a greater disparity in gonad dry weight between kelp-bed and barren urchins for larger urchin volumes. No differences in the rate of increase in gonad dry weight were observed between experimental urchins maintained on laboratory feeding regimes and those collected from their respective habitats in the field (barren state, $t=-0.407, \mathrm{p}=0.69$; kelp-bed state, $t=0.627$, $\mathrm{p}=0.5)$. Model fit is shown in Table 1 .

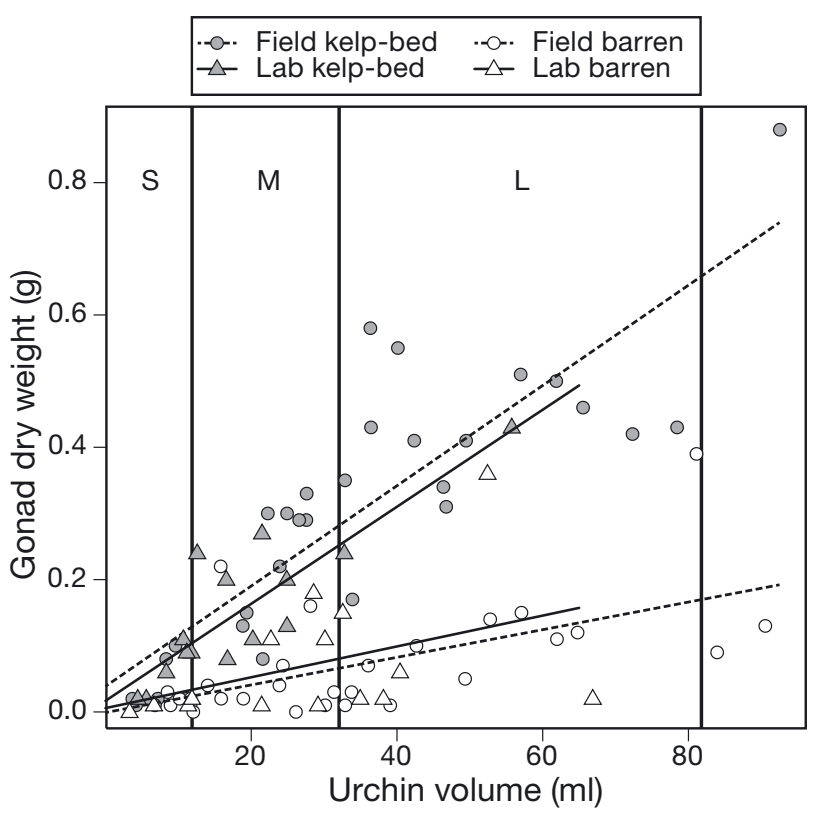

Fig. 3. Urchin gonad dry mass (g) and urchin volume (ml) for field kelp-bed $\left(O_{1}---\right)$, lab kelp-bed $(\triangle,-)$, field barren $(O,---)$, and lab barren $\left(\Delta_{,},-\right)$urchins. Urchin size classes used in the laboratory trials (S: small; M: medium; L: large) shown by thick vertical lines. Intercepts among groups were not significantly different from each other (all $p>0.5$ ) and not significantly different from zero $(t=0.996, \mathrm{p}=0.3)$. Slopes were significantly different between urchin states (lab $t=4.434, \mathrm{p}<0.001$, field $t=7.811, \mathrm{p}<0.001$ ). Slopes were not significantly different between lab and field urchins within urchin states (barren: $t=-0.407, \mathrm{p}=0.69$; kelp-bed: $t=0.627, \mathrm{p}=0.5$ )

\section{DISCUSSION}

Lobsters preferred kelp-bed urchins to barren urchins when presented together. While larger urchins were consumed at a lower rate than smaller urchins, the relative preference for kelp-bed urchins increased with urchin size, potentially due to the greater disparity in gonad weights between kelp-bed and barren urchins at larger urchin sizes. These results imply that lobsters can distinguish between the 2 urchin-states and can actively make a choice based on the nutritional status of the urchin. The mechanism by which lobsters make this distinction is unknown but could potentially be mediated by lobsters' ability to detect chemical differences in the urchins or their feces (Cobb \& Phillips 1980) or through differences in morphology of urchins associated with barrens such as longer, thinner spines, as has been shown for urchins in Australia (Ling \& Johnson 2009). As a result of this preference for kelpbed urchins, predation rates on urchins in barrens 
may be lower than expected if well-fed urchins from kelp forests or other preferred prey are also available, as may be the case for barren patches within otherwise intact kelp forests.

The results from trials where barren urchins were offered alone may give more insight about what might occur when a reserve is established in an area with a large continuous barren. In trials where only one urchin-state was offered to a lobster at a time, the small and medium lobsters still showed significantly higher feeding rates on kelp-bed urchins, and for the small lobster, barren urchins were avoided completely. For large lobsters, predation rates were similar between kelp-bed and barren urchins when offered alone. However, an apparent lack of preference for kelp-bed urchins by large lobsters may be an artifact of their efficient and rapid feeding rates. Large lobsters tended to consume most or all of the urchins provided, which lowered our ability to detect a preference due to the frequency of our sampling. Thus it is possible that initial feeding rates were higher on kelp urchins, but we were unable to detect it. Personal observation of predation in the tanks does suggest kelp urchins were chosen first, but additional studies that tracked the order in which urchins were eaten could solidify this claim. In fact, this laboratory situation may rarely occur in the field, in that large lobsters will simply avoid barrens due to a lack of highquality prey.

Alternatively, a larger lobster may more readily include barren urchins in its diet despite their lower energy content because large lobsters have (1) higher energy demands, and (2) a greater payoff in terms of net energy gained because of shorter handling times. If large lobsters do consume urchins from barrens at a comparable rate when they are the only prey available, time lags may still occur because it takes time for lobsters to grow to large sizes following marine reserve establishment, but these time lags will be shorter than that expected with an absolute preference for kelp-bed urchins.

The higher predation rates on kelp-bed urchins when presented alone and simultaneously with barren urchins gives insight to the dynamics of urchin barrens, and more specifically, highlights a possible explanation as to why and how urchin barrens are resistant to change in marine reserves. It has been shown that there are time lags in urchin population responses after predators, such as lobsters, are protected or brought back to a natural abundance (Babcock et al. 2010). Urchin cryptic behavior and size thresholds for urchin predation have been proposed as reasons why it takes a relatively long time ( $>5 \mathrm{yr})$ for urchin populations to decrease (Shears \& Babcock 2003, Babcock et al. 2010), but our study suggests predator avoidance of urchins in barrens could also be a critical factor.

Predator avoidance of urchins in barrens may also operate in other kelp forest systems with urchin predators, such as the northwestern Atlantic, New Zealand, and Australia (Pinnegar et al. 2000). However, it is important to recognize other urchin predators exist in Southern California, particularly the California sheephead (Teleostei: Semicossyphus pulcher). Whether urchin barrens will persist following marine reserve establishment, may depend on whether these other urchin predators also avoid urchins from barrens.

Avoidance of urchins from barrens by predators because of low urchin quality is a novel mechanism that could explain why a phase shift from an urchin barren back to kelp forest might happen more slowly than previously thought. A potential feedback mechanism could be operating here: as a result of lobster avoidance of barren urchins, those urchins in barrens may remain at high density and with the consequent low gonad weight that appears to make predation less likely. In addition, lobster preference for urchins in kelp forests may act to prevent urchin outbreaks and the formation of urchin barrens.

\section{CONCLUSIONS}

The results provide a note of caution regarding expectations of recovery of urchin barrens in the newly established marine reserves within the range of the spiny lobster in California (California Department of Fish and Wildlife 2012) as well as in reserves in other kelp forests with lobsters as urchin predators. This process may take longer and might even need an outside mechanism, such as storms (Ebeling et al. 1985) or disease (Lafferty 2004), to initiate the transition. By understanding how predator foraging behavior can affect urchin barren phase shifts in kelp forests, we can better manage these ecological and economically important marine habitats.

Acknowledgements. We thank G. Graves, S. Holbrook, R. Schmitt, and N. Shears for their comments and feedback, S. Gosnell for statistics consultation, and K. Eurich, D. Okamoto, J. Schem, D. Macaskill, and E. Samuel for their aid in conducting the experiment. This research was supported by funds awarded to J.G.E. by the University of California, 
Santa Barbara Undergraduate Research and Creative Activities Grant. R.L.S. was supported by a National Science Foundation Graduate Research Fellowship and a National Defense Science and Engineering Graduate fellowship. This is publication no. 443 from the Partnership for Interdisciplinary Studies of Coastal Oceans (PISCO), a long-term ecological consortium, which is partially funded by the David and Lucile Packard Foundation and the Gordon and Betty Moore Foundation. This manuscript was improved by Romuald Lipcius and 3 anonymous reviewers.

\section{LITERATURE CITED}

Babcock RC, Shears NT, Alcala AC, Barrett NS and others (2010) Decadal trends in marine reserves reveal differential rates of change in direct and indirect effects. Proc Natl Acad Sci USA 107:18256-18261

Bates D, Maechler M, Bolker B (2011) lme4: linear mixedeffects model using $\mathrm{S} 4$ classes. $\mathrm{R}$ package version 0.999375-42. http://CRAN.R-project.org/package=lme4

> Behrens MD, Lafferty KD (2004) Effects of marine reserves and urchin disease on southern Californian rocky reef communities. Mar Ecol Prog Ser 279:129-139

Bellwood DR, Hoey AS, Hughes TP (2011) Human activity selectively impacts the ecosystem roles of parrotfishes on coral reefs. Proc R Soc Lond B Biol Sci 279:1621-1629

Blackwood JC, Hastings A, Mumby PJ (2012) The effect of fishing on hysteresis in Caribbean coral reefs. Theor Ecol 5:105-114

Bolker BM, Brooks ME, Clark CJ, Geange SW, Poulsen JR, Stevens HH, White JSS (2009) Generalized linear mixed models: a practical guide for ecology and evolution. Trends Ecol Evol 24:127-135

California Department of Fish and Wildlife (2012) Guide to the Southern California marine protected areas: Point Conception to California-Mexico border. California Department of Fish and Wildlife, Sacramento, CA

Chapman ARO (1981) Stability of sea urchin dominated barren grounds following destructive grazing of kelp in St. Margaret's Bay, Eastern Canada. Mar Biol 62:307-311

Claisse JT, Williams JP, Ford T, Pondella DJ II, Meux B, Protopapadakis L (2013) Kelp forest habitat restoration has the potential to increase sea urchin gonad biomass. Ecosphere 4:art38

Cobb S, Phillips B (1980) The biology and management of lobsters: physiology and behavior. Academic Press, New York, NY

Crawley MJ (2007) The R book, 1st edn. Wiley, Chichester

Dayton PK, Sala E, Tegner MJ, Thrush S (2000) Marine reserves: parks, baselines, and fishery enhancement. Bull Mar Sci 66:617-634

> Dodge CA, Edwards MS (2011) Seasonal variation in the effects of food availability on gametogenesis in the purple urchin (Strongylocentrotus purpuratus). Mar Biol 159:427-433

Ebeling AW, Laur DR, Rowley RJ (1985) Severe storm disturbances and reversal of community structure in a southern California kelp forest. Mar Biol 84:287-294

Ebert TA (1965) A technique for the individual marking of sea urchins. Ecology 46:193-194

Edgar GJ, Barrett N, Stuart-Smith R (2009) Exploited reefs protected from fishing transform over decades into conservation features otherwise absent from seascapes. Ecol Appl 19:1967-1974
Foster MS, Schiel DR (2010) Loss of predators and the collapse of southern California kelp forests (?): alternatives, explanations and generalizations. J Exp Mar Biol Ecol 393:59-70

> Gosnell J, Gaines S (2012) Keystone intimidators in the intertidal: non-consumptive effects of a keystone sea star regulate feeding and growth in whelks. Mar Ecol Prog Ser 450:107-114

> Graham MH (2004) Effects of local deforestation on the diversity and structure of Southern California giant kelp forest food webs. Ecosystems 7:341-357

Green AL, Bellwood DR (2009) Monitoring functional groups of herbivorous reef fishes as indicators of coral reef resilience - a practical guide for coral reef managers in the Asia Pacific Region. In: Green AL, Bellwood DR (eds) IUCN Resilience Science Group Working Paper Series. IUCN, Gland, p 1-70

> Harrold C, Reed DC (1985) Food availability, sea urchin grazing, and kelp forest community structure. Ecology 66:1160-1169

Heatfield BM (1971) Growth of the calcareous skeleton during regeneration of spines of the sea urchin, Strongylocentrotus purpuratus (Stimpson): a light and scanning electron microscopic study. Morphology 134:57-89

> Hughes TP, Rodrigues MJ, Bellwood DR, Ceccarelli D and others (2007) Phase shifts, herbivory, and the resilience of coral reefs to climate change. Curr Biol 17:360-365

Krivan V, Sikder A (1999) Optimal foraging and predator prey dynamics, II. Theor Popul Biol 55:111-126

> Lafferty KD (2004) Fishing for lobsters indirectly increases epidemics in sea urchins. Ecol Appl 14:1566-1573

Lafferty KD, Kushner DJ (2000) Population regulation of the purple sea urchin, Strongylocentrotus purpuratus at the California Channel Islands. In: Brown DR, Mitchell KL, Chang HW (eds) Marine ecology. Proc 5th Cal Isl Symp. Minerals Management Service Publication, Santa Barbara, CA, p 379-381

Lawrence J (2001) Edible sea urchins: biology and ecology. Elsevier, Amsterdam

> Lester S, Halpern B, Grorud-Colvert K, Lubchenco J and others (2009) Biological effects within no-take marine reserves: a global synthesis. Mar Ecol Prog Ser 384: 33-46

Ling SD, Johnson CR (2009) Population dynamics of an ecologically important range-extender: kelp beds versus sea urchin barrens. Mar Ecol Prog Ser 374:113-125

Ling SD, Johnson CR (2012) Marine reserves reduce risk of climate-driven phase shift by reinstating size- and habitat-specific trophic interactions. Ecol Appl 22: 1232-1245

> Ling SD, Johnson CR, Frusher SD, Ridgway KR (2009) Overfishing reduces resilience of kelp beds to climate-driven catastrophic phase shift. Proc Natl Acad Sci USA 106: 22341-22345

> McClanahan TR, Muthiga NA (1989) Patterns of predation on a sea urchin, Echinometra mathaei (de Blainville), on Kenyan coral reefs. J Exp Mar Biol Ecol 126:77-94

> McCook LJ (1999) Macroalgae, nutrients and phase shifts on coral reefs: scientific issues and management consequences for the Great Barrier Reef. Coral Reefs 18: 357-367

Micheli F, Halpern BS, Botsford LW, Warner RR (2004) Trajectories and correlates of community change in no-take marine reserves. Ecol Appl 14:1709-1723

> Mumby PJ (2009) Phase shifts and the stability of macroalgal 
communities on Caribbean coral reefs. Coral Reefs 28: 761-773

Nakagawa S, Schielzeth H (2013) A general and simple method for obtaining $R^{2}$ from generalized linear mixedeffects models. Methods Ecol Evol 4:133-142

Norström A, Nyström M, Lokrantz J, Folke C (2009) Alternative states on coral reefs: beyond coral-macroalgal phase shifts. Mar Ecol Prog Ser 376:295-306

Nyström M, Folke C, Moberg F (2000) Coral reef disturbance and resilience in a human-dominated environment. Trends Ecol Evol 15:413-417

Pinnegar JK, Polunin NVC, Francour P, Badalamenti F and others (2000) Trophic cascades in benthic marine ecosystems: lessons for fisheries and protected-area management. Environ Conserv 27:179-200

R Development Core Team (2011) R: a language and environment for statistical computing. R Foundation for Statistical Computing, Vienna

Editorial responsibility: Romuald Lipcius,

Gloucester Point, Virginia, USA
Rita H, Komonen A (2008) Odds ratio: an ecologically sound tool to compare proportions. Ann Zool Fenn 45:66-72

Scheffer M, Carpenter S, Foley JA, Folke C, Walker B (2001) Catastrophic shifts in ecosystems. Nature 413:591-596

Shears NT, Babcock RC (2003) Continuing trophic cascade effects after 25 years of no-take marine reserve protection. Mar Ecol Prog Ser 246:1-16

Stewart NL, Konar B (2012) Kelp forests versus urchin barrens: alternate stable states and their effect on sea otter prey quality in the Aleutian Islands. Mar Biol 2012:1-12

Tegner M, Dayton P (2000) Ecosystem effects of fishing in kelp forest communities. ICES J Mar Sci 57:579-589

Tegner M, Levin L (1983) Spiny lobsters and sea urchins: analysis of a predator-prey interaction. J Exp Mar Biol Ecol 73:125-150

Zuur A, Ieno E, Walker N, Saveliev A, Smith G (2009) Mixed effects models and extensions in ecology with $R$. Springer, New York, NY

Submitted: July 18, 2013; Accepted: November 11, 2013 Proofs received from author(s): January 28, 2014 